\title{
Organizational Justice and Whistleblowing: An Experimental Test
}

\author{
Abraham Kurniawan ${ }^{1}$, Intiyas Utami ${ }^{1 *}$ and David Ade Chandra Ashedica Pesudo ${ }^{1}$ \\ 1) Accounting Department, Faculty of Economic and Business, Universitas Kristen Satya Wacana \\ Л. Diponegoro 52-60 Salatiga, Indonesia \\ *Corresponding author, Email: intiyas@staff.uksw.edu
}

\begin{abstract}
Whistleblowing has become an important issue at the organization recently because it enables individuals to disclose any regulation's errors in the organization to their superior. Whistleblowing could be caused by several factors, one of which is organizational justice. The organizational justice consists of distributive justice and procedural justice. The objective of this research is to examine the causality of organizational justice to whistleblowing intention. This research was conducted with $2 \times 2$ between-subjects experimental design. The results show that when an individual is faced with fair distributive justice or fair procedural justice, they have the tendency to whistle the fraud. When an individual is faced with unfair procedural justice and fair distributive justice, they also tendto whistle the fraud.
\end{abstract}

Keywords: Whistleblowing intention, organizational justice, procedural justice, distributive justice

\section{INTRODUCTION}

The issue of this research is whistleblowing in the context of accounting that gives space for individuals to report conditions that are not following the organization's regulation to a higher level management(s). Research on whistleblowing had been done by [3] and [24]. They have found that the importance of whistleblowing in preventing or detecting errors, as well as in uncovering agency's problems.

Indonesia had already experienced a whistleblowing case in PT Asian Agri Group's tax embezzlement. This case started with Vincentius Amin Sutanto's (Vincent/VAS) act of breaking into PT AAG's safe in Fortis Bank of Singapore in 13 November 2006, taking USD 3,1 million with him. When he was reported to Polda Metro Jaya (Greater Jakarta Metropolitan Regional Police), VAS escaped to Singapore and took some of his company's important documents. On 1 December 2006, VAS deliberately went to $K P K$ (Corruption Eradication Commission) to reveal PT AAG's financial problems, fully equipped with several financial documents and digital data. One of the documents is entitled "AAA-Cross Border Tax Planning (Under Pricing of Export Sales)" that contained all PT AAG's detailed pricing transfer preparation.

A research by [2] found that if an internal auditor is faced with a consequence, they will not whistle blow the case. However, [16] found that senior auditor will report a breach of the code of ethics when the cost of disclosure is low and when their responsibility in reporting the case is high. From the two previously mentioned research, it can be concluded that internal auditor will do a whistleblowing when the consequences of the disclosure are low and when the auditor's responsibility is high. The key of success in whistleblowing is in organizational policy [13]. Things that were included in organizational policy are witnesses' responsibility to report wrongdoing, reporting channels, and organizational efforts to protect whistleblowers from retaliation [15]. Other organizational factors that affect whistleblowing are organizational response on whistleblowing report [27], ethical environment [10], internal reward for whistleblowing [5] [30], as well as external administration in the form of report hotline [29] [31].

Whistleblowing is also one of the factors that improves corporate governance [3]. Fairness in the organization becomes a driving factor of whistleblowing. [26] said that an organizational justice's fair process helps to improve the success of whistleblowing. According to [14], organizational justice is a concept about how someone is being treated in an organization. [7] and [26] found that there are three components that could be used to test organizational justice, they are: distributive, procedural, and interactional. Individual evaluation of reward allocation refers to distributive justice, while procedural evaluation in deciding that allocation refers to procedural justice [9]. Interactional 
justice refers to the way the management (or those who control the rewards and resources) respond to the recipient of justice [7]. Although these three types of justice are theoretically assumed to be strongly related to employees' attitude, empirical evidence also shows that the three types of justice are sometimes overlapping [7] [8].

[4] found that if a company has a good fraudulence report structure, the auditor will most certainly disclose the fraud and believe firmly that this act will not have an effect to their career. [28] researched whistleblowing and organizational justice in the context of management accounting and internal audit. They found that companies that applied the code of ethics were also required to place their focus on fairness for their employees. There were some discussions on the internal auditor's role as a whistleblower, as well as their role in detecting fraud and proposing obedience are still being questioned more critically than their previous role [30]. Research that focused on testing the causality of organizational justice with whistleblowing in the context of internal audit with the task of detecting fraud is still severely limited. Those are the underlying cause of why this research is testing the causality between whistleblowing and organizational justice in the context of the internal auditor.

Organizational justice in the context of an internal audit that became the focus of this research is procedural justice and distributive justice. With good corporate governance, internal auditor becomes the reporting party that should report to top management if there is any indication of fraudulence. With that, interaction justice between subordinate and supervisor could not happen because the internal auditor turns into someone who received reports from the staffs under him/her instead. This research aims to give empirical evidence on the causality of organizational justice in the form of distributive and procedural in whistleblowing cases. This research gives contribution in developing behavioral research, especially in the field of internal audit which explains whistleblowing with organizational justice. This research also gives inputs to organizations in designing an effective whistleblowing policy and procedure.

\section{Whistleblowing Intention}

The effectivity of a mechanism in detecting errors in a company received bad reputation with the disclosure of two biggest frauds in United States financial report: Enron and WorldCom [3]. That disclosure was followed by the collapse of the stock market and similar business that forces American Congress to create an act, The Corporate
Criminal Fraud Accountability Act, in July 2002, which is better known as the Sarbanes-Oxley Act of 2002. This act (on section 301 and 806) specifically push employees to do whistleblowing and gives them the means to avoid any kinds of revenge that are directed to employees who reveal the company's secret information.

In their research, [12] found that there is a decrease in fraud revealment after the Sarbanes Oxley Act from $20.7 \%$ to $15.6 \%$. Many accountants and employees of Enron and WorldCom believed that the numbers of that financial report were not correct but still chose to keep their silence.

\section{Organizational Justice}

In accordance with the Structural Model that was done by researchers [4] [30] as well as whistleblowing researchers [11] [19] summarized that whistleblowing is a pro-social behavior that is categorized as a voluntary act and an individual's role in revealing an error.

Organizational justice theory has the potency to be a contributor in implementing an effective whistleblowing mechanism because some previous research found that there is a positive relation in the dimension of justice and pro-social behavior [7] [8]. If employees feel fairly treated by their company, they will do positive things for the company, such as whistleblowing [7]. Organizational justice theory gives a framework in creating a structural mechanism that aims for an increase in employees' potential in whistleblowing.

[8] stated that organizational justice has been socially constructed but not normatively defined. There are two dimensions of organizational justice, fairness in the process (procedural justice) and fairness in the result (distributive justice). Procedural justice is related to compensation budgeting process mechanism while distributive justice is a level which considered it normal for an individual to receive compensation from the organization.

\section{Distributive Justice and Whistleblowing Intention}

Distributive justice focuses on the fairness of result and is the first dimension of organizational justice [1]. Previous research proposed that a fair resolution on whistleblowing will increase the reports of an error [19]. Distributive justice suggested that when a whistleblower risked a revenge for themselves because of a report, they will be hoping for organizations to respond by investigating the report and stopping the error [1] [20].

Previous research has got the relation between distributive justice and pro-social behavior [7] [8]. Internal revealment of an error should be positively interlinked when whistleblowing mecha- 
nism is consistent with distributive justice. Based on past arguments and research results, the hypothesis of this research is:

H1: Whistleblowing intention in a fair distributive justice condition will be higher than whistleblowing decision in an unfair distributive justice condition.

\section{Procedural Justice and Whistleblowing Intention}

Procedural intention focused on the fairness of the process, which is the second dimension of justice on the research about organizational justice. Consistency of procedure, free from bias when making a decision, correcting inaccurate decision making, procedures that follow the ethical standard, and consideration of group's opinion when executing procedure are some of the things that procedural justice should have [8]

Past research has found that to increase error report, rules/act about whistleblowing should be consistent, free from bias, and fair [6] [18] [20] [26] [28]. With that, it can be concluded from previous research that the fairer the procedural justice, the higher the whistleblowing tendency will also be [7] [8] [23]. From the arguments above, the second hypothesis of this research is:

$\mathrm{H} 2$ : The desire to whistle blow in a fair procedural justice will be higher than it is in unfair procedural justice.

\section{RESEARCH METHOD}

The design of this research is between subjects laboratory experiment. Independent variables of this research are procedural justice and distributive justice, as part of the organization justice. Each independent variables has two levels: fair and unfair, while the dependent variable is whistleblowing intention. The subjects of this research are accounting students that have taken the auditing course, who serves as internal auditor surrogate, facing fraud case in their duty. College students could be used as an experimental subject as long as the task(s) do not require them to have specific skills and experience [21]. Experimental activities are done in the form of guest lectures and internal audit duty is a part of internal audit simulation. To take care of the demand effect on the experiment, where subjects act unnaturally and have the tendency to give responses that are not based on the given manipulation, some experiments are led by the experimenter. Experimenter gives instruction according to the designed experimental protocol. The simulation module had been tested through the pilot test on small and medium groups, as well as to internal audit practitioner. Experimental matrix could be seen in table 1 .
Table 1. Experimental Matrix

\begin{tabular}{cclc}
\hline & & \multicolumn{2}{l}{ Distributive Justice } \\
\cline { 3 - 4 } & & Fair & Unfair \\
\hline Procedural & Fair & Sel 1 & Sel 2 \\
Justice & Unfair & Sel 3 & Sel 4 \\
\hline
\end{tabular}

The researcher used pens and papers for the experiments. The first stage used randomization, participants were chosen at random without caring about their intelligence or skill level, gender, and age. They then received one of the four prepared modules. The experimenter explained how to fill in the modules and the participants followed every instruction given at the same time.

In the second stage, participants read the business profile and were tested on their understanding and mastery on basic information related to audit and accounting with whistleblowing intention. All the participants' judgment was only influenced by the manipulation given.

In the third stage, participants received manipulation on the existing fraud information and the fairness felt, that is fair procedural justice, unfair procedural justice, fair distributive justice, and unfair distributive justice. At the end of the case, participants gave judgment of whistleblowing intention based on the received manipulation with the score from 1 to 10 . After manipulations were given, participants answered questions and manipulation internalization that is consisted of five questions. If participants could answer three questions correctly, they were declared to be free from manipulation.

In the closing stage, participants were given debriefing that aimed to give an explanation to the subject on the given situations and turn the subject back into their original condition. On that phase, experimenter explained the purpose of the activity and was then ended with the closing.

\section{RESULTS}

The subject of this research is 80 undergraduate students who studied Accounting in STIE PERBANAS Surabaya. The manipulation check result shows as much as sixty-two (62) participants from eighty (80) participants. The characteristics of each participant are divided into 4 categories: GPA, semester, age, and gender as shown in Table 2 . After getting subject who passed the manipulation check, the researcher tested the effectivity of randomization with One Way ANOVA. This test is meant to get the assurance that the experiment is done randomly and there is no influence of demographic characteristics such as gender, GPA, semester, and age on whistleblowing intention. With that, the only manipulation affected whistleblowing intention. 
Table 2. Randomization Effectivity Test

\begin{tabular}{|c|c|c|c|c|c|c|c|}
\hline & \multicolumn{3}{|c|}{ Procedural Info } & \multicolumn{3}{|c|}{ Distributive Info } \\
\hline & & $\begin{array}{c}\text { Mean } \\
\text { Square }\end{array}$ & $\mathrm{F}$ & Sig. & $\begin{array}{l}\text { Mean } \\
\text { Square }\end{array}$ & $\mathrm{F}$ & Sig. \\
\hline \multirow{2}{*}{ Gender } & \multirow{2}{*}{$\begin{array}{l}\text { Between- } \\
\text { group } \\
\text { Intergroup }\end{array}$} & 40,938 & 5,318 & 0,025 & 0,019 & 0,002 & 0,964 \\
\hline & & 7,697 & & & 9,324 & & \\
\hline \multirow{2}{*}{ Age } & \multirow{2}{*}{$\begin{array}{l}\text { Between- } \\
\text { group } \\
\text { Intergroup }\end{array}$} & 8,068 & 0,977 & 0,440 & 5,023 & 0,526 & 0,755 \\
\hline & & 8,258 & & & 9,541 & & \\
\hline \multirow[t]{2}{*}{ GPA } & $\begin{array}{l}\text { Between- } \\
\text { group }\end{array}$ & 19,246 & 2,446 & 0,095 & 1,111 & 0,118 & 0,889 \\
\hline & Intergroup & 7,869 & & & 9,444 & & \\
\hline \multirow[t]{2}{*}{ Semester } & $\begin{array}{l}\text { Between- } \\
\text { group }\end{array}$ & 11,224 & 1,379 & 0,260 & 5,763 & 0,621 & 0,541 \\
\hline & Intergroup & 8,141 & & & 9,287 & & \\
\hline
\end{tabular}

The first hypothesis test was done using independent t-test by comparing whistleblowing intention on fair and unfair distributive justice condition. This test is the main effect test. The result of the test can be seen in table 3 below.

Table 3. Hypothesis 1 Test

\begin{tabular}{lcccc}
\hline & N & Mean & $\begin{array}{c}\text { Deviation } \\
\text { Standard }\end{array}$ & T-test (Sig) \\
\hline Procedural Info & & & & \\
$\quad$ Fair & 33 & 8,73 & 1,180 & $17.322(0,000)$ \\
$\quad$ Unfair & 29 & 3,52 & 1,184 & \\
\hline
\end{tabular}

The test result shows that the whistleblowing intention value of subject groups that received fair distributive justice information is 8,73 on average, while participants that received unfair distributive justice information has whistleblowing intention value of 3,52 on average. This shows that subjects with fair distributive justice information have more tendency to report fraud than those who received unfair distributive justice information.

The second hypothesis test used independent t-test by comparing information on fair and unfair procedural justice. The test result can be seen in table 4 below.

Table 4. Hypothesis 2 Test

\begin{tabular}{lcccc}
\hline & N & Mean & $\begin{array}{c}\text { Deviation } \\
\text { Standard }\end{array}$ & T-test (Sig) \\
\hline Procedural Info & & & & \\
$\quad$ Fair & 30 & 8,17 & 1,341 & $13,665(0,000)$ \\
Unfair & 32 & 2,94 & 1,645 & \\
\hline
\end{tabular}

The test result shows that participant groups that received fair procedural justice information have the average score of 8,17 . Participant groups that received unfair procedural justice have the average score of 2,94. This shows how auditor who received fair procedural justice information is more willing to report things or condition that are not following the rules.
The statistic test result shows sig (2-tailed) score to be 0,000 , which is lower than alpha $(0,05)$. Thus, it can be concluded that there is a significant difference between groups who were given fair and unfair procedural justice information. Based on the average, it can be concluded that groups who received fair procedural justice information are more willing to report frauds.

\section{DISCUSSION}

Hypothesis one, based on the tests, is declared as supported, as there is causality relation between distributive justice by comparing whistleblowing intention of groups who were given fair and unfair distributive justice information. The same result with [26]. Distributive justice suggested that when whistleblower risked revenge on themselves when they reported on an error, they will hope for the organization to respond by investigating the report and stopping that error [1] [20]. This research supported all research that declared that there is a causality relation between distributive justice and pro-social behavior [7] [8].

The second hypothesis test shows that there is a difference in an individual's whistleblowing intention in fair and unfair procedural justice condition. This research result confirmed the statements of several other researchers [18] [20] [22] [28] that regulation that controlled whistleblowing should be consistent, free from bias, and fair, so that it could increase the number of reports on fraud through the process. This result also supported previous research [8] [23] [25] [26] that the fairer the procedural justice, the higher the tendency to do whistleblowing.

\section{CONCLUSION, LIMITATION AND FUTURE RESEARCH}

The aims of this research are to verify the causality connection between organizational justice with the decision to do whistleblowing. This research has successfully given the empirical evidence that organizational justice indeed has influences on the intention to do whistleblowing. Individuals who found indications of fraud will be more inclined to report the fraud when the condition of procedural or distributive justice is fair. However, when there is a fair procedural justice and unfair distributive justice, individuals would have the inclination to not report the case.

For companies, this research contributes to creating policy, especially on a fair distributive justice that could increase the potency of whistleblowing so that the financial report's reliability could be accounted for. 


\section{REFERENCES}

[1] Adams, J. S. (1965). Inequity In Social Exchange. In Advances in Experimental Social Psychology (Vol. 2, pp. 267-299). Elsevier. https://doi.org/10.1016/S0065-2601(08)60108-2

[2] Arnold, D. F., \& Ponemon, L. A. (1991). Internal Auditors' Perceptions of Whistle-Blowing and the Influence of Moral Reasoning: An Experiment, 16.

[3] Bowen, R. M., Call, A. C., \& Rajgopal, S. (2010). Whistle-blowing: Target firm characteristics and economic consequences. The Accounting Review, 85(4), 1239-1271. https://doi.org/10.2308/accr.2010.85.4.1239

[4] Brennan, N., \& Kelly, J. (2007). A study of whistleblowing among trainee auditors. The British Accounting Review, 39(1), 61-87. https://doi.org/10.1016/j.bar.2006.12.002

[5] Brink, A. G., Lowe, D. J., \& Victoravich, L. M. (2013). The Effect of Evidence Strength and Internal Rewards on Intentions to Report Fraud in the Dodd-Frank Regulatory Environment. AUDITING: A Journal of Practice \& Theory, 32(3), 87-104. https://doi.org/10.2308/ ajpt-50449

[6] Callahan, E. S., \& Dworkin, T. M. (1994). Who blows the whistle to the media, and why: Organizational characteristics of media whistleblowers. American Business Law Journal, 32(2), 151-184.

[7] Cohen-Charash, Y., \& Spector, P. E. (2001). The Role of Justice in Organizations: A MetaAnalysis. Organizational Behavior and $\mathrm{Hu}$ man Decision Processes, 86(2), 278-321.

[8] Colquitt, J. A., \& Rodell, J. B. (2011). Justice, Trust, and Trustworthiness: A Longitudinal Analysis Integrating Three Theoretical Perspectives. Academy of Management Journal, 54(6), 1183-1206. https://doi.org/10.5465/amj. 2007.0572

[9] Cropanzano, R., \& Greenberg, J. (1997). Progress in Organizational Justice: Tunneling Through the Maze. In International review of industrial and organizational psychology (pp. 317-372). New York: Wiley.

[10] Dalton, D., \& Radtke, R. R. (2013). The Joint Effects of Machiavellianism and Ethical Environment on Whistle-Blowing. Journal of Business Ethics, 117(1), 153-172. https://doi.org/10. 1007/s10551-012-1517-x

[11] Dozier, J. B., \& Miceli, M. P. (1985). Potential Predictors of Whistle-Blowing: A Prosocial Behavior Perspective. The Academy of Management Review, 10(4), 823-836. https://doi.org/ $10.2307 / 258050$

[12] Dyck, A., Morse, A., \& Zingales, L. (2007). Who Blows the Whistle on Corporate Fraud? DYCK - 2010 - The Journal of Finance - Wiley Online Library. Retrieved July 3, 2018, from https://onlinelibrary.wiley.com/doi/abs/10.1111 /j.1540-6261.2010.01614.x

[13] Gao, L., \& Brink, A. G. (2017). Whistleblowing studies in accounting research: A review of experimental studies on the determinants of whistleblowing. Journal of Accounting Literature, 38, 1-13.

[14] Greenberg, J. (1990). Organizational Justice: Yesterday, Today, and Tomorrow, Organizational Justice: Yesterday, Today, and Tomorrow. Journal of Management, 16(2), 399-432. https://doi.org/10.1177/014920639001600208

[15] Hassink, H., Vries, M. de, \& Bollen, L. (2007). A Content Analysis of Whistleblowing Policies of Leading European Companies. Journal of Business Ethics, 75(1), 25-44. https://doi.org/ 10.1007/s10551-006-9236-9

[16] Kaplan, S. E., \& Whitecotton, S. M. (2001). An Examination of Auditors' Reporting Intentions When Another Auditor Is Offered Client Employment. AUDITING: A Journal of Practice \& Theory, 20(1), 45-63. https://doi.org/10. 2308/aud.2001.20.1.45

[17] Macey, J. (2007). Getting the Word Out About Fraud: A Theoretical Analysis of Whistleblowing and Insider Trading. Faculty Scholarship Series. Retrieved from http://digitalcommons.law.yale.edu/fss_papers/1383

[18] Miceli, M. P., \& Near, J. P. (1989). The incidence of wrongdoing, whistle-blowing, and retaliation: Results of a naturally occurring field experiment. Employee Responsibilities and Rights Journal, 2(2), 91-108. https://doi. org/10.1007/BF01384940

[19] Miceli, M. P., Near, J. P., \& Dworkin, T. M. (2009). A Word to the Wise: How Managers and Policy-Makers can Encourage Employees to Report Wrongdoing. Journal of Business Ethics, 86(3), 379-396. https://doi.org/10.1007/ s10551-008-9853-6

[20] Miceli, M. P., Near, J. P., \& Schwenk, C. R. (1991). Who Blows the Whistle and Why. Industrial and Labor Relations Review, 45(1), 113-128.

[21] Nahartyo, E., \& Utami, I. (2015). Panduan Praktis Riset Eksperimen. Penerbit Indeks. Retrieved from http://www.indeks-penerbit. com/index.php?route=product/product\&produ ct_id $=614$

[22] Near, J. P., Rehg, M. T., Van Scotter, J. R., \& Miceli, M. P. (2004). Does Type of Wrongdoing Affect the Whistle-Blowing Process? Business Ethics Quarterly, 14(02), 219-242. https://doi. org/10.5840/beq200414210.

[23] Podsakoff, P. M., \& MacKenzie, S. B. (1993). Citizenship behavior and fairness in organizations: Issues and directions for future research. Employee Responsibilities and Rights Journal, 6(3), 257-269. https://doi.org/10.1007/ BF01419449 
[24] Schmidt, M. (2005). "Whistle Blowing" regulation and accounting standards enforcement in Germany and Europe-An economic perspective. International Review of Law and Economics, 25(2), 143-168.

[25] Seifert, D. L., Stammerjohan, W. W., \& Martin, R. B. (2014). Trust, Organizational Justice, and Whistleblowing: A Research Note. Behavioral Research in Accounting, 26(1), 157-168. https://doi.org/10.2308/bria-50587

[26] Seifert, D. L., Sweeney, J. T., Joireman, J., \& Thornton, J. M. (2010). The influence of organizational justice on accountant whistleblowing. Accounting, Organizations and Society, 35(7), 707-717.

[27] Taylor, E. Z., \& Curtis, M. B. (2013). Whistleblowing in Audit Firms: Organizational Response and Power Distance. Behavioral Research in Accounting, 25(2), 21-43. https://doi. org/10.2308/bria-50415.
[28] Treviño, L. K., \& Weaver, G. R. (2001). Organizational Justice and Ethics Program "FollowThrough": Influences on Employees' Harmful and Helpful Behavior. Business Ethics Quarterly, 11(4), 651-671. https://doi.org/10.2307/ 3857765

[29] Utami, I., Jori, A., \& Hapsari, A. N. S. (2017). Sudikah Akuntan Mengungkap Aib Kecurangan? Jurnal Akuntansi Multiparadigma, 8(3), 458-469. https://doi.org/10.18202/jamal. 2017.12.7066

[30] Xu, Y., \& Ziegenfuss, D. E. (2008). Reward Systems, Moral Reasoning, and Internal Auditors' Reporting Wrongdoing. Journal of Business and Psychology, 22(4), 323-331. https://doi.org/10.1007/s10869-008-9072-2

[31] Zhang, J., Pany, K., \& Reckers, P. M. J. (2013). Under Which Conditions are Whistleblowing "Best Practices" Best? AUDITING: A Journal of Practice \& Theory, 32(3), 171-181. https://doi.org/10.2308/ajpt-50451 